Por motivos personales, la autora ha solicitado que este texto sea retirado

\title{
Athenea Digital
}

15 de octubre de 2012

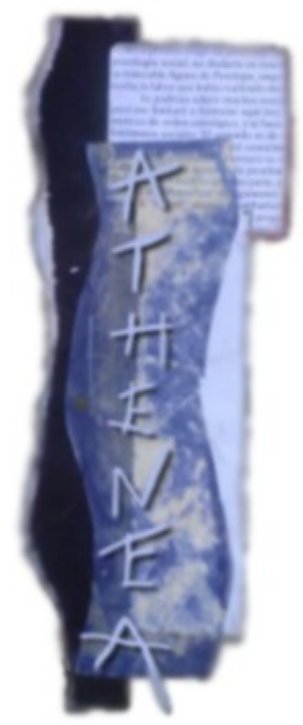

